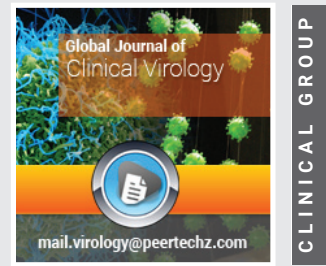

\section{Oksana Kukalo*}

National Medical Academy of Postgraduate Education named, After P. L. Shupyk, Ukraine

Received: 18 July, 2019

Accepted: 14 November, 2019

Published: 15 November, 2019

*Corresponding author: Oksana Kukalo, National Medical Academy of Postgraduate Education named After P. L. Shupyk, Ukraine,

E-mail: oksana.kukalo@ukr.net

Keywords: Respiratory viruses; New respiratory viruses; Bronchopulmonary diseases; Infectious exacerbation of bronchial asthma; Molecular genetic technologies; Multiplex PCR; Real-time PCR

https://www.peertechz.com

Check for updates

\section{Research Article}

Molecular-Genetic Technologies and their places in the Ethyological Diagnosis of the Infectious Combination of Bronchial Asthma

\section{Introduction}

Broncho-pulmonary respiratory diseases through viral etiologic factors are one of the leading causes of morbidity and mortality especially among children, the elderly and patients with immunodeficiency. Most clinical signs and symptoms of human bronchopulmonary infections caused by respiratory viruses are similar, and some of them can affect a certain population of different age groups with a manifestation of a serious clinical picture, and sometimes lead to rapid deaths. In a large proportion of patients with acute respiratory infections, it is difficult to determine clinical factors. Today, $50 \%$ of adults with pneumonia have not identified the etiology of the onset, $15 \%$ of bronchitis and $35 \%$ of pneumonia among the children still have an unidentified etiological factor, clinical forms and the diagnosis cannot be finally established [1-3]. A great variety pathogenic microorganism contributes to infant bronchopulmonary diseases, including bacteria; however, worse viruses are more likely to be responsible for bronchitis, bronchiolitis, asthmatic conditions, obstructive pulmonary disease.

In the world about 300 million people suffer from bronchial asthma (BA). The prevalence of asthma in different countries ranges from 1 to $18 \%$. According to experts, from the complications of this chronic illness, about 250,000 people per year die. A significant number of patients are hospitalized annually due to severe infectious asthma. In the examination and treatment of patients with acute exacerbation of asthma it is extremely important to timely diagnose the etiological factor of exacerbation, which enables to adequately prescribe treatment, reduce the duration and severity of clinical course [4]. According to the results of modern studies, triggers of exacerbation of asthma may have been various environmental factors, numerous bacterial and viral etiopathogeneses $[5,6]$. From the 1960's began to talk about viruses as one of the main factors of exacerbation of asthma. After the involvement in the medical practice of the polymerase chain reaction (PCR) method in the 1990s, the role of respiratory viruses in infectious exacerbation of asthma (BA) has been finally confirmed. Epidemiological and immunopathophysiological studies show that the most common cause of exacerbation of asthma in $80 \%-85 \%$ of cases in children and in $60 \%-$ $70 \%$ of adults are acute respiratory viral infections (ARIs). And although infectious exacerbations of BA depend on other factors (phenotypic, anamnestic, from the previous basic treatment, duration of exacerbation, etc.), these figures point to the colossal role of viruses in this process [7-10]. Thus, the human respiratory syncytial virus (hRsv) is the most important cause of bronchopulmonary disease in children, which in turn results in approximately 200,000 deaths and more than 3 million hospitalizations per year [7,11]. Other clinically 
important respiratory viruses are found in patients with bronchopulmonary diseases - these are known for us influenza A and B viruses, human Rhinovirus (hRv), parainfluenza viruses 1,2,3 and 4 (human parainfluenza virus-1-4 hPiv ) and adenoviruses of groups $\mathrm{B}, \mathrm{C}$ and $\mathrm{E}$ (human adenovirus $\mathrm{B}, \mathrm{C}, \mathrm{E}-$ hAdv). In addition, recently, scientists have appeared where the causes of bronchopulmonary disease are "new" respiratory viruses: human coronavirus (human Coronavirus-hCov) and its new serotypes, human parvovirus, human bacavirus (human bocavirus-hBov), human metapneumatic brain (Human Metapneum Virus-hMpv) $[12,13]$. Such results were achieved by scientists through the development and implementation of molecular genetic technologies with real-time detection, in laboratory practice. Today, several molecular genetic technologies are used in the world to determine the presence of certain nucleotide sequences of pathogens with the help of real-time fluorescence detection, of which the most wellknown are technologies using a 5 'end labeled oligonucleotide probe (TaqMan), technology.

Purpose: to establish the place of molecular genetic technologies in the etiological diagnosis of infectious exacerbation of bronchial asthma and to identify new respiratory viral pathogens among the etiological factors in patients with infectious exacerbation of bronchial asthma

\section{Materials and Methods of Research}

The study included 116 patients with BA: 52(44.8\%) males and $64(55.2 \%)$ women aged $20-82$ years (mean age $-(50.4 \pm 1.5)$ years) who were examined and treated in ambulatory conditions of the State University "National Institute of Phthisiology and Pulmonology. FG Yanovsky National Academy of Medical Sciences of Ukraine "(NIFF NAMN). Patients performed general examination methods in accordance with the order of the Ministry of Health of Ukraine No. 128 dated 19.03.2007. The anamnestic, clinical data (general condition of the patient, limitation of its activity, presence and level of abnormalities of consciousness, language, character and level of shortness of breath, cough, number and character of sputum, clinical manifestations of acute respiratory infections (hyperemia of soft palate and posterior choroidal wall, menstruation, rhinitis, abdominal sweating, weakness, photophobia, joint and muscle pain, headache), involvement in the support of the muscles of the breath, auscultatory data (the presence and nature of wheezing), body temperature, respiratory rate, blood pressure , heart rate (heart rate), etc.

For virological examination in all patients, a biomaterial flask was performed in the form of washes or smears from the mucous membrane of the nasopharynx, if necessary bronchoalveolar lavage $[9,10,14,15]$. For sampling of biological material (smears from the nasal cavity of patients), work on molecular genetic panels, used swabs: FLOQS hwabs velortampon, manufactured by COPAN, Italy; Viscose or dacron tampon-JS tampon, manufactured by Jiangsu Suyun Medical Materials Co., Ltd, China, in some cases, cytosolite "ZGU-CM", manufactured by Centromed, Russia. The strokes were taken by dry sterile swabs with dacrynum, rabbit or velor swabs, and in order to prevent inactivation of the viruses, placed in a 2.0- 3.oml test tube of a special universal transport medium for biological samples "UTM for the collection and preservation of Virus, Clamidia, Mycoplasma, Ureaplasma "produced by Copan Diagnostics (Italy), or 3.0ml of storage medium for respiratory viruses (VTS) ("AmpliSens"Russia) [14]. The tip of a swab with a swab broke the mark in the city or cut off with sterile knifes in the calculation of the ability to close the lid of the transport tube tightly. The test tube with the transport medium and part of the probe was closed and placed on a special tripod and transported to the laboratory. Biological material in the number of 116 specimens for research was taken from patients of the State University "National Institute of Phthisiology and Pulmonology. F. Yanovsky was transported in containers with a refrigerant at a temperature of $+4^{\circ} \mathrm{C}$ to the laboratory of the Department of Virology at the National Medical Academy of Postgraduate Education named after P. L. Shupyk, Ministry of Health of Ukraine (Head of the Department, Dr. of Medical Sciences, professor Dzyublyk I.V)

The following sets were used for the isolation of nucleic acids (NK): Ribotopter, AmpliSens (Russia) and NucleoSpin Dx Virus, VACHEREY-NAGELTM, Seegene (Korea), VIASURE RNADNA Extraction Kit (Certest Biotec SL) (Spain). Extraction in microflute technology on a chip in PCR-RF was performed on UltraFast Sample Prep G2-16TU equipment for the selection of Viral DNA/RNA Prep Kit - Swab \& Stool NANOBIOSYS. For reverse transcription, the sets of «Reverta-L», «AmpliSens» (Russia) and «cDNA Synthesis Premix V1.1», manufactured by Seegene (Korea), VIASURE $\rightarrow$ Master Mix Kits are designed for Conventional PCR, Real Time PCR, Sequencing, etc. Certest Biotec S.L. Zaragoza, (Spain).

Detection was performed using a set of Allplex ${ }^{\mathrm{TM}}$ Respiratory Full Panel reagents with primers for up to 26 respiratory pathogens (Seegene, Korea, consisting of 4 different panels for identifying and identifying 16 types of viruses, 7 bacteria and 3 influenza A subtypes, Amplisence $\rightarrow$ GVVI-Scrin -FL with primers to 13 viral pathogens) (FBUN TsNIIE RF), respiratory viral panel I -VIASURE Flu A, Flu B \& RSV Real Time PCR Detection Kit VIASURE for simultaneous detection of influenza A, influenza A and respiratory syncytial (RSV) viruses and subtypes of influenza A (H1N1) pdm09, H3N2, H5N1 and H7N9, CerTest VIASURE MULTIPLEX Resistance to three pathogens: Adenovirus, Metapneumovirus, Bocavirus (MULTIPLEX Respiratory Viral Panel I - Certest Biotec S.L, Spain); NBC LabChip Adenovirus, Metapneumovirus, Respiratory syncytial virus with primers for three respiratory viruses.

For analysis and interpretation of the results, modern detectionequipmentwasused:PSC-FRTRotor-GeneQ(QIAGEN), manufactured by Germany; Rotor-Gene 6000 Corbett Research (Australia); CFX96 Bio-Rad, Singapore, PacBioRS Pacific Biosciences, CA; LightCycle 2.o Roche Life Science, Switzerland; UltraFast Real-Time PCR G2-4 LabChip MiCo Nanobiosys, Korea. The data obtained during the study process was processed by the method of math statistics using the Microsoft Excel and IBM SPSS Statistics 20 software packages (SPSS Inc., USA), the Seegene Viewer software, which is installed additionally and uses the results of the control program PCR (CFX Manager). 


\section{Results and Discussion}

Several technologies have been used to determine the presence of certain nucleotide sequences of the receptor viruses using "real-time" fluorescence detection, of which the most well-known are methods with SYBR Green intercalating dye and technology with specific probes based on destruction of oligonucleotide samples (TaqMan) and pin structures (Scorpions) The choice of detection method is extremely important for the test system, since each method has its advantages and disadvantages, its scope and characteristics. The use of the 5 'end tag cleavage technology (TaqMan Assay) is based on the use of 5'-exonuclear polymerase activity. These probes have landing sites within the amplified area, which is typical for the AmplisSense $\rightarrow$ GRVI-scrine-FL -13 set. The gasser quenches the radiating fluorescent label of radiation, and the phosphate group in the 3'-position blocks the polymerase. The probe, which is burnt on the matrix, unfolds, and the fluorescent label and the dummy diverge in different directions. Thus, the intensity of the glow increases, which allowed to conduct and detect in real time from 2 to 4 independent reactions, using probes labeled with different fluorescence dyes (multiplex PSCRFR) in a single vial. The TaqMan technology based on the destruction of the LNA (locked nucleic acids) oligonucleotide probes can achieve high sensitivity and specificity of the test system and overcome such shortcomings of other approaches as low specificity and frequent false positives, as well as the awkwardness of work associated with the need for a test in two separate test tubes for an intercalating dye SYBR Green I. The TaqMan assay is based on the $5^{\prime}$-nuclease activity of Taq polymerase that cleaves nucleotides from oligonucleotide probes, Hibrizovannyh DNA. You need two TaqMan probes with different polymorphic sites. One probe should be complementary to the wild allele, another - polymorphic variants. These probes have different 5 '-end fluorescent dyes and fluorescence suppressors at the 3 ' end. When the probes are inactive, the duster interacts with the dye using the FRET mechanism, blocking the fluorescence activity. At the stage of annealing of primers in the process of PCR, TaqMan probes hybridize with the DNA molecule. At the stage of disintegration, the $5^{-}$-end of the dye is cleaved, due to the 5 -nucleus activity of Taq polymerase, which leads to an increase in the fluorescence of the dye. False mating of the bases in the probes leads to the splitting of the whole probe without release of the dye $[6,16]$.

The principle of the VIASURE procedure is that the respiratory virus panel is based on this principle. Realtime PCR detection kit is designed to diagnose influenza A, and PCR viruses and subtypes of influenza A pdmo9 (H1N1), $\mathrm{H} 3 \mathrm{~N} 2, \mathrm{H} 5 \mathrm{~N} 1$, and / or clinical H7N9 specimens. Detection is carried out in one stage in real time format RT, where reverse transcription and subsequent amplification of a specific target sequence occurs in one reaction mixture. The isolated RNA target is transcribed, which generates complementary DNA by reverse transcription, after which conservative parts of the M1 gene for influenza A and influenza $\mathrm{B}$ and the $\mathrm{N}$ gene for RSV and the hemagglutinin gene for influenza A ((H1N1), pdmo9, H3N2 subtypes are amplified) , H5N1, and / or H7N9) using special primers and labels with fluorescence probes.
VIASURE respiratory viral PCR-RF is based on 5'-exonuclear DNA polymerase activity. During DNA amplification, this enzyme cleaves a probe coupled to a complement of a DNA sequence that separates the quench dye from the reporter. This reaction generates an increase in the fluorescence signal, proportional to the amount of the target template and detected in real time. Despite many years of experience with molecular genetic panels for the detection of respiratory pathogens, there is relatively little data on the clinical effects of multiplexing testing. Previous diagnostic studies of respiratory panels showed that fast dyeing of direct fluorescent antibodies from NP specimens could reduce hospital stay, minimize auxiliary testing and reduce unnecessary use of antibiotics in children [16-18]. Is there an advantage of more sensitive molecular tests that detect a wider range of potential pathogens? An analysis of the costs of inpatient pediatric treatment assessed the duration of stay in the broncho-pulmonary disease department, the use of antibiotics and diagnostic procedures to conclude that molecular genetic multiplexed PCRs are the least expensive tests in diagnostic strategies, such as the prevalence of respiratory disease $\geq 11 \%$ [12]. Testing Multiplex molecular technology can also be cost-effective for children with influenza-like SARs, which are assessed in the Emergency Department and [13].

The application of the technology PCR-FRT DPO ${ }^{\mathrm{TM}}$ (Dual Priming Oligonucleotide) is a technology with a special component of the primer design - a PCR component that is responsible for the high specificity of the entire PCR method, has allowed detection of amplification products in the reaction process and a semi-quantitative record of viral nucleic acids. This approach allowed the abandonment of the electrophoresis stage, which contributed to a reduction in the probability of contamination of the samples under study with amplification products, and also allowed to reduce the requirements presented to the PSC laboratory $[19,20]$.

Using the TOCE ${ }^{\mathrm{TM}}$ technology has allowed simultaneous identification of several target targets in the same detection channel. To detect the presence of target targets, the signal was measured in real time and analyzed at the melting point of the Catcher-probe (Catcher-Tm). The Catcher probe is one of the unique features of TOCE ${ }^{\mathrm{TM}}$ technology. It is a fluorescently labeled artificially synthesized DNA probe that generates a signal for each target sequence. The value of the Catcher-Tm can be controlled by controlling the sequence and length of the Catcher probe. To optimize the TOCE ${ }^{\mathrm{TM}}$ analysis, the CatcherTm value is easily adjusted and not limited to the target sequence. The key components of the TOCE ${ }^{\mathrm{TM}}$ technology are a pair of DPO primers, and a pair of probes - "Pitcher" and "Catcher" allegorically functionally close to the name of the baseball players that is translated into serving and catching). DPO-primers provide highly-specific amplification of the target site (amplicon). "Pitcher" is an artificially synthesized assembled oligonucleotide that hybridizes to the corresponding sequence in the middle of the target site. "Catcher" is an artificially steninated fluorescently labeled oligonucleotide. Cyclic analysis of melting temperature Catcher. Target detection and search and their semi-quantitative results can be obtained at the same time by installing a cyclic CMTA algorithm in the real-time PCR process. The cyclic-CMTA protocol can be 
set to $20,30,40$ cycles of PCR (or other value). The result is interpreted depending on the number of melting peaks and the number of targets, as shown in the table of the results of the analysis. The above analysis is performed using the Seegene Viewer software application, which is installed additionally and uses the results of the control program PCR (for example, CFX Manager). Seegene Viewer allows you to: Read multiple sample results at a time. Display the results of all charts for each $\mathrm{Ct}$ in one channel. Get results by automatically interpreting data. Integrate test results by patient ID or sample.

The difference in the time of the melting peak at the point of cMTA indicates the different titres of the target (low, medium and high) in the sample. In this example, the peak of melting the HPV 33 genotype appears at the first point of the CMTA on a cycle of 20 that corresponds to a large number of copies. The HPV 16 genotype appears at the second point of the cMTA in the 30th cycle, and corresponds to an intermediate amount of copies. The HPV 18 genotype appears in the third point of the CMTA in 40 cycles, corresponding to a low copy count. Such measurements allow for quantitative analysis, stability and treatment of several HPV genotypes simultaneously, helping to control the viral load associated with cervical cancer incidence. As an interim conclusion, I will fix that the TOCE technology together with the syclic-CMTA algorithm can confirm the multiple (five or more) target targets. A profile of information obtained through multiplex PCR analysis can significantly accelerate accurate diagnosis, and hence treatment. Thus, the principle of molecular genetic testing, proposed by Seegene, leads to a paradigm shift in molecular diagnosis regarding the speed and quality of testing that is needed to optimize patient care. None of the real-time PCR-based hardware-reagent solutions available in the world can detect more than 6 targets in a single sample at a time. The Seegene solution allows you to receive semi-quantitative data from a PCR result of up to 15 targets simultaneously.

MuDT $^{\mathrm{TM}}$ Technology (Multiple Detection Temperatures) MuDT $^{\mathrm{TM}}$ in our version is used for Allplex ${ }^{\mathrm{TM}}$ Panels-26 Seegene-the most advanced multi-detection and analysis technology for Real-Time PCR results that opens a new era in molecular diagnostics. Combined with DPO and TOCE technologies, it physically eliminates the "one goal - one channel" obstacle. Now, when conducting the PCR-RP (CFX96 example) in one detection channel it is possible to define several targets for the individual value of Ct. Thanks to this technology, the criterion of multiplexing is realized fundamentally, expanding the functionality by using the channels of existing Real-Time PCB platforms. This molecular technology has allowed us to get results about individual value Ct of several pathogenic microorganisms on one channel in real time of the PCR tool. Results from Allplex ${ }^{\mathrm{TM}} 26$ Seegene Respiratory Panels allow faster, more reliable, and comprehensive testing of results than any other technology combined with Seegene's automation platforms. In their researches, Kevin Barratt of the New Zealand Kenteburian Laboratory conducted the comparison of various multiplex molecular technologies for detection. respiratory etiopathogens and showed that the efficacy of the tests was the same, the analysis of the technology MuDT ${ }^{\mathrm{TM}}$ Seegene had the advantage of simultaneously detecting two gene targets for each of the most common The subtypes of influenza A had better bandwidth of 30 samples per one set and automatic analysis of the results [21-27] .

We first introduced microfluidic microfluidic microprocessor technology UltraFast LabChip Real-Time PCR G2-4 System, which combines Lab on-a-Chip (LabChip) technology with PCR-PCR detection-a modern know-how technology using polymeric materials (Figure 1 ).

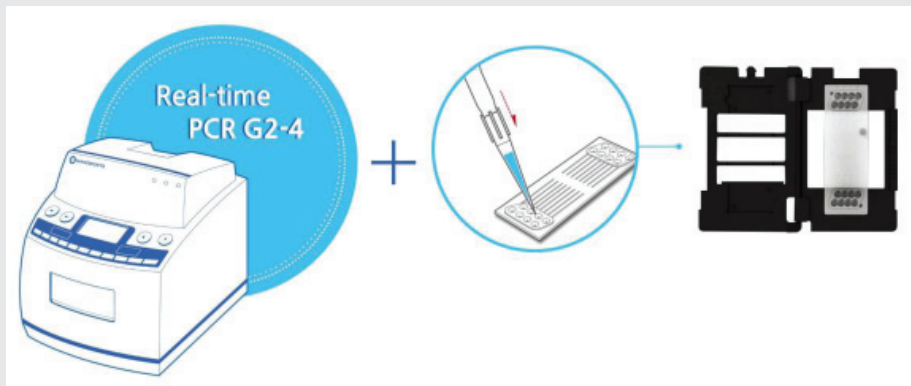

Figure 1: UltraFast LabChip Real-Time PCR G2-4 System microfluidic microprocessor technology.

This is a new, ultra-fast, portable polymerase chain reaction (PCR) system that runs on a chip-based real-time basis. In particular, PCR in real time based on liquid chips attracted attention to its ability to rapidly quantitatively analyze the pathogens of infectious diseases due to its excellent sensitivity and specificity. We conducted a PCR-RH based on current. This technology is based on the circulation of preheated liquids in a microfuid chip that thermalizes the PCR chamber with diffusion and ultrahigh-speed switches of currents. The system can reach up to 30 cycles of PCR-RF and for about 2 minutes, making it the fastest PCR thermal system for regular sample volumes. This allowed for an operational quantitative analysis ( 15 minutes for performing 30 PCR cycles in real time). Using clinical samples of influenza $\mathrm{A} / \mathrm{H} 1 \mathrm{~N} 1$, we found that real-time PCBs based on fluid chips had excellent sensitivity and specificity that were almost identical to the usual PCR$\mathrm{RF}$. The following criteria were taken into consideration when working with this technology: reaction rate, small volumes of biological samples and desirable disposable materials for pollution prevention, as well as low cost. Such detection is accordingly 6.4 and 7.2 times faster than when using the device without fields, while maintaining the volume of PCR samples in real-time, efficiency, selectivity and sensitivity. High-speed thermalization also allowed us to analyze the fusion curve for $20 \mathrm{~s}$ and to allocate amplicons of different lengths using realtime fast PCR. This thermostat thermostat system of the PCR system in real time mode is cost effective, versatile and can be used in multiplex, ultrasound and high-sensitivity molecular tests to detect viral etiopathogens in IBS.

According to the data of the laboratory examination of 116 patients, using a series of molecular genetic technologies with real-time detection and multiplex format, the range of major viruses in the etiology of infectious exacerbation of bronchial asthma was detected - in $60(51.7 \pm 4.6) \%$ of the 
cases, viral etiopathogens were detected in $21((18,1 \pm 3,6) \%)$ of the patient is a bacterial etiopathogen and in $10((8,62 \pm 2,6) \%)$ of patients-a viral and bacterial pathogen. With the aid of various molecular genetic techniques, 60 strains of viruses were identified by the multiplex PCR-RP method. The greatest etiological significance among viral pathogens was rhinovirus - in $(55,0 \pm 6,4) \%$ of cases. Significantly less was detected by bacavirus - in (10.0 \pm 3.9$) \%$ of cases; metapneumatic - in $(8,3 \pm 3,6) \%$; respiratory syncytial virus - in $(6.7 \% \pm 3.2 \%)$, influenza A and B - $(5.0 \pm 2.8 \%)$ each, corona, adenovirus and parainfluenza virus - in $(3.3 \pm 2,3) \%$ of cases each (Table 1$)$.

Among the $60 \%(51,7 \pm 4,6)$ of patients with BA, viral pathogens were identified. The greatest etiopathogenetic

Table 1: Viral markers identified by different methods using the proposed algorithm - schemes for improving the diagnosis of infectious exacerbation of bronchial asthma.

\begin{tabular}{|c|c|c|c|c|c|c|c|c|c|c|}
\hline \multirow{3}{*}{$\begin{array}{l}\text { Identified viral } \\
\text { etiopathogen }\end{array}$} & \multicolumn{8}{|c|}{$\begin{array}{l}\text { Viral markers identified by different methods using the proposed algorithm - schemes for improving the diagnosis of infectious } \\
\text { exacerbation of bronchial asthma }\end{array}$} & \multirow{2}{*}{$\begin{array}{l}\text { Circulation } \\
\text { among } \\
\text { patients }\end{array}$} & \multirow{2}{*}{$\begin{array}{l}\text { Distribution } \\
\text { among viral } \\
\text { pathogens }\end{array}$} \\
\hline & \multicolumn{7}{|c|}{ Molecular - genetic technologies of PCR in relief time multiplex format } & \multirow[b]{2}{*}{$\begin{array}{l}\text { Quick } \\
\text { Tests } \\
\\
\\
\\
\text { IHA } \\
\text { (immune } \\
\text { chromato } \\
\text { graphic) }\end{array}$} & & \\
\hline & $\begin{array}{l}\text { MULTIPLEX } \\
\text { "APPLICATION } \\
\text { OF ORVI- } \\
\text { SCREEN-FL" } \\
\text { Panel } 12 \\
\text { with TaqMan } \\
\text { probes and } \\
\text { detecting the } \\
\text { fluorescence } \\
\text { accumulation } \\
\text { of target PCR } \\
\text { products }\end{array}$ & $\begin{array}{l}\text { MULTIPLEX } \\
\text { Allplex }{ }^{\mathrm{TM}} \text { and } \\
\text { Respiratory } \\
\text { Full Panel } 26 \\
\text { using one-stage } \\
\text { technology } \\
\text { using MuDT } \\
\text { technology } \\
\text { with the detection } \\
\text { of the individual } \\
\text { Ct value of several } \\
\text { target PCR } \\
\text { products in one } \\
\text { spectral channel }\end{array}$ & $\begin{array}{l}\text { MULTIPLEX with } \\
\text { Anyplex }{ }^{T M} \text { II - Respiratory } \\
\text { Panel 16- using } \\
\text { technology using DPO }{ }^{\mathrm{TM}} \\
\text { technology and the } \\
\text { TOCE }^{\mathrm{TM}} \text { melting curve } \\
\text { analysis method } \\
\text { detecting the change in } \\
\text { the melting temperature } \\
\text { of several target PCR } \\
\text { products in a single } \\
\text { spectral channel }\end{array}$ & \begin{tabular}{|c|} 
MULTIPLEX \\
Allplex $^{\mathrm{TM}}$ \\
Assays \\
Respiratory \\
Full Panel 26 \\
using MuDT \\
Technology \\
with the \\
detection of \\
the individual \\
Ct value of \\
several target \\
PCR products \\
in one spectral \\
channel
\end{tabular} & $\begin{array}{l}\text { MULTIPLEX } \\
\text { Respiratory } \\
\text { Viral Panel } \\
\text { VIASURE } \\
\text { Using } \\
\text { Detection of } \\
\text { Fluorescent } \\
\text { Reporter } \\
\text { Dyes }\end{array}$ & $\begin{array}{l}\text { MULTIPLEX ACE } \\
\text { Seeplex® RV15 } \\
\text { using DPO }{ }^{\text {M }} \\
\text { (Dual Priming } \\
\text { Oligonucleotide) }\end{array}$ & $\begin{array}{c} \\
\\
\text { UltraFast } \\
\text { LabChip } \\
\text { Real-time } \\
\text { PCR }\end{array}$ & & $\begin{array}{c}\% \\
\mathrm{n}=116\end{array}$ & $\mathrm{n}=60$ \\
\hline Adenovirus & 2 & 2 & 2 & 2 & 2 & 2 & 2 & 2 & $1,7 \pm 1,2$ & $3,3 \pm 2,3$ \\
\hline Erythrovirus & 6 & 6 & 6 & 6 & 6 & 6 & - & - & $5,2 \pm 2,1$ & $10,0 \pm 3,9$ \\
\hline Rhinovirus & 33 & 33 & 33 & 33 & 33 & 33 & - & - & $28,5 \pm 4,2$ & $55,0 \pm 6,4$ \\
\hline $\begin{array}{l}\text { Rhinovirus is } \\
\text { unattached }\end{array}$ & 21 & 21 & 21 & 21 & 21 & 21 & - & - & $24,5 \pm 3,6$ & $12,6 \pm 3,8$ \\
\hline Rhinovirus 1 & 4 & 4 & 4 & 4 & 4 & 4 & - & - & $33,4 \pm 1,7$ & $6,7 \pm 3,2$ \\
\hline Rhinovirus 2 & 2 & 2 & 2 & 2 & 2 & 2 & - & - & $21,7 \pm 1,2$ & $3,3 \pm 2,3$ \\
\hline Rhinovirus3 & 5 & 5 & 5 & 5 & 5 & 5 & - & - & $4,3 \pm 1,9$ & $8,3 \pm 3,6$ \\
\hline Rhinovirus 4 & 1 & 1 & 1 & 1 & 1 & 1 & - & - & $0,9 \pm 0,9$ & $1,7 \pm 1,7$ \\
\hline $\begin{array}{l}\text { Respiratory } \\
\text { syncytial virus }\end{array}$ & 4 & 4 & 4 & 4 & 4 & 4 & 4 & 4 & $33,4 \pm 1,7$ & $6,7 \pm 3,2$ \\
\hline $\begin{array}{l}\text { Methapneum } \\
\text { virus }\end{array}$ & 5 & 5 & 5 & 5 & 5 & 5 & 5 & - & $4,3 \pm 1,9$ & $8,3 \pm 3,6$ \\
\hline Corona virus & 2 & 2 & 2 & 2 & 2 & 2 & - & - & $1,7 \pm 1,2$ & $3,3 \pm 2,3$ \\
\hline $\begin{array}{l}\text { Corona virus } \\
\text { WL-63229E- }\end{array}$ & 1 & 1 & 1 & 1 & 1 & 1 & - & - & $0,9 \pm 0,9$ & $1,7 \pm 1,7$ \\
\hline $\begin{array}{l}\text { Corona virus } \\
\text { NKI-10S-42 }\end{array}$ & 1 & 1 & 1 & 1 & 1 & 1 & - & - & $0,9 \pm 0,9$ & $1,7 \pm 1,7$ \\
\hline $\begin{array}{c}\text { Corona virus } \\
\text { MERS }\end{array}$ & - & - & - & - & - & - & - & - & - & - \\
\hline $\begin{array}{c}\text { Influenza A } \\
\text { virus }\end{array}$ & 3 & 3 & 3 & 3 & 3 & 3 & 3 & 3 & $2,6 \pm 1,5$ & $5,0 \pm 2,8$ \\
\hline $\begin{array}{c}\text { Influenza B } \\
\text { virus }\end{array}$ & 3 & 3 & 3 & 3 & 3 & 3 & 3 & 3 & $2,6 \pm 1,5$ & $5,0 \pm 2,8$ \\
\hline $\begin{array}{l}\text { Parainfluenza } \\
\text { virus }\end{array}$ & 2 & 2 & 2 & 2 & 2 & 2 & - & - & $1,7 \pm 1,2$ & $3,3 \pm 2,3$ \\
\hline $\begin{array}{c}\text { Human } \\
\text { Parainfluenza } \\
\text { virus } 1\end{array}$ & - & - & - & - & - & - & - & - & - & - \\
\hline $\begin{array}{c}\text { Human } \\
\text { Parainfluenza } \\
\text { virus } 2\end{array}$ & - & - & - & - & - & - & - & - & - & - \\
\hline $\begin{array}{l}\text { Human } \\
\text { Parainfluenza } \\
\text { virus } 3\end{array}$ & 2 & 2 & 2 & 2 & 2 & -2 & & & $1,7 \pm 1,2$ & $3,3 \pm 2,3$ \\
\hline $\begin{array}{c}\text { Human } \\
\text { Parainfluenza } \\
\text { virus } 4\end{array}$ & - & - & - & - & - & - & - & & - & - \\
\hline Total & 60 & 60 & 60 & 60 & 60 & 60 & 17 & 11 & $51,7 \pm 4,6$ & 100 \\
\hline & & & & & & & & & & 005 \\
\hline
\end{tabular}

Citation: Kukalo O (2019) Molecular-Genetic Technologies and their places in the Ethyological Diagnosis of the Infectious Combination of Bronchial Asthma. Glob J Clin Virol 4(1): 001-007. DOI: https://dx.doi.org/10.17352/gjcv.000005 
significance in the induction of acute exacerbation of asthma has been demonstrated by Rhinovirus, $55.0 \%$ (Rhinovirus type $3-8.3 \%$ Rhinovirus type $1-6.7 \%$, Rhinovirus type $2-3.3 \%$, Rhinovirus type 4-1.7\%, Rhinovirus non-typical-24.0\%) cases. Bacavirus was found to be less common in $10.0 \%$ of cases, Methapneumovirus-8.3\%, Respiratory syncytial virus-6.7\%, Influenza $\mathrm{A}$ virus and $5.0 \%$ Influenza virus, Parainfluenza virus type $3-3.3 \%$, Coronavirus NL-63, E-229 and Coronavirus HKUI-1, OS -43 by $1.7 \%$. Among isolated bacterial strains in the significant titre: H. influenzae - in $(38,1 \pm 10,6) \%$ of cases, S pneumoniae - in $(38,1 \pm 10,6) \%$, M. catarrhalis - in $(14,3 \pm 7.6) \%$, E. coli and S. aureus - in $(0.9 \pm 0.9) \%$ each.

\section{Conclusions}

For the first time, molecular genetic technologies for asthma diagnostics were used. The place of molecular genetic technologies in the etiological diagnosis of infectious exacerbation of bronchial asthma is established and it is the key to preventing the aggravation and spread of this disease. This in turn allows us to make proper clinical decisions in terms of treating patients with asthma and to mitigate the growth of drug-resistant pathogens. Molecular genetic technologies are fast and accurate in detecting an etiological agent anywhere. Microfluid molecular - genetic technologies of PCR - RF are universal and ultra-fast (15 min), Specific and sensitive to the identification of etiological pathogens from BA. The use of modern molecular genetic techniques of the real-time multiplex real-time PCR method made it possible to confirm the etiological role of viruses in exacerbating bronchial asthma in 60 patients $(51,7 \pm 4,6) \%)$ and greatly expanded the possibility of obtaining real results through its undeniable advantages: high specificity, sensitivity, versatility of procedure, simplicity and convenience of analysis, the possibility of simultaneous detection of several pathogens at once.

Due to these technologies, for the first time in biological material from adult patients, "new" viruses in the development of diseases of the bronchopulmonary system were detected in $21.7 \%$. For the first time in patients, Bocavirus was detectedin $10.0 \%$ of cases, Methapneumovirus-8.3\%, Coronavirus NL-63, E-229 and Coronavirus HKUI-1, OS-43 by $1.7 \%$. In turn, the definition of viral etiology for a short time prevents the ineffective use of antibiotics, provides time for antiviral therapy and promotes the spread of infection.

The prospects for further research are the development and scientific substantiation of the algorithm of laboratory diagnostics of asthma based on the application of modern molecular genetic technologies for the identification of viral and bacterial pathogens, and the evaluation of molecular genetic technology research in the multiplex format available for the diagnosis of hostile infections of the lower respiratory tract.

\section{References}

1. Ralston SL, Lieberthal AS, Meissner HC, Alverson BK, Baley JE, et al. (2014) Clinical practice guideline: the diagnosis, management, and prevention of bronchiolitis. Pediatrics 134: e1474-e1502. Link: http://bit.ly/20cd9VN
2. Bronchiolitis Guideline Team, Cincinnati Children's Hospital Medica Center. Bronchiolitis pediatric evidence-based care guidelines, 2010. Link: http://bit.ly/2KkEkwp

3. Brealey JC, Sly PD, Young PR, Chappell KJ (2015) Viral bacterial co-infection of the respiratory tract during early childhood. FEMS Microbiol Lett 362. Link: http://bit.ly/2pdCiH8

4. Dulek DE, Peebles RS (2011) Viruses and Asthma. Biochim Biophys Acta 1810: 1080-1090. Link: http://bit.ly/2Qoynmh

5. Labinskaya AS, Blinkova LP, Eshchina AS (2005) Private medical microbiology with appliances microbiological studies. Moskow, Meditsina 432-461.

6. Dublik IV, Kukalo OV, Solomko you, Okhotnikova OM, Sharikadze OV, et al. (2016) Laboratory diagnostics algorithm for detection of respiratory viral and bacterial infectious agents in children with bronchial obstruction syndrome.

7. Loeffelholz M, Chonmaitree T (2010) Advances in diagnosis of respiratory virus infections. Int J Microbiol 2010: 126049. Link: http://bit.ly/32NfM5Q

8. Folkerts G, Busse WW, Nijkamp FP, Sorkness R, Gern JE (1998) Virus-induced airway hyperresponsiveness and asthma. Am J Respir Crit Care Med 157 1708-1720. Link: http://bit.ly/2CKojM5

9. Dzyblyk IV, Obertynska OV (2012) Polymerase chain reaction in the laboratory diagnosis of infectious diseases. Kyiv, NMAPO 200

10. Skala LZ (1997) Practical aspects of modern clinical microbiology. Moskow, TOO" LABINFORM". 184

11. Van den Hoogen BG, Osterhaus DM, Fouchier RA (2004) Clinical impact and diagnosis of human metapneumovirus infection. Pediatr Infect Dis $\mathrm{J} 23$ : S25-S32. Link: http://bit.ly/34Y8pKe

12. Mahony JB, Blackhouse G, Babwah J, Smieja M, Buracond S, et al. (2009) Cost analysis of multiplex PCR testing for diagnosing respiratory virus infections. $J$ Clin Microbiol 47: 2812-2817. Link: http://bit.ly/2pgY3WC

13. Nelson RE, Stockmann C, Hersh AL, Pavia AT, Korgenksi K, et al. (2015) Economic analysis of rapid and sensitive polymerase chain reaction testing in the emergency department for influenza infections in children. Pediatr Infect Dis J 34: 577-582. Link: http://bit.ly/2rEATdv

14. Methodological Recommendation Delivery of goods, transported by material in accordance with the dispensing method -NEC 662,

15. Shyrobokov VP (2011) Medical Microbiology, Virology and Immunology. Vinnytsya, Nova knyga.

16. Dzublik IV, Kukalo OV, Solomko YO (2016) Detection and identification of influenza virus and other respiratory pathogens by multiplex real-time polymerase chain reaction.

17. Barenfanger J, Drake C, Leon N, Mueller T, Troutt T (2000) Clinical and financial benefits of rapid detection of respiratory viruses: an outcomes study. J Clin Microbiol 38: 2824-2828. Link: http://bit.ly/2qNZ8Wu

18. Woo PC, Chiu SS, Seto WH, Peiris M (1997) Cost-effectiveness of rapid diagnosis of viral respiratory tract infections in pediatric patients. J Clin Microbiol 35: 1579-1581. Link: http://bit.ly/2Qkywqv

19. Cho CH, Lee CK, Nam MH, Yoon SY, Lim CS, et al. (2014) Evaluation of the AdvanSure realtime RT-PCR compared with culture and Seeplex RV15 for simultaneous detection of respiratory viruses. Diagn Microbiol Infect Dis 79 14-18. Link: http://bit.ly/351R03j

20. Kim H, Hur M, Moon HW, Yun YM, Cho HC (2014) Comparison of two multiplex PCR assays for the detection of respiratory viral infections. Clin Respir $\mathrm{J} 8$ 391-396. Link: http://bit.ly/2KkNpFv

21. Barratt K, Anderson TP, Fahey JA, Jennings LC, Werno AM (2017) Comparison of rapid dynamics of respiratory 21 and Seegene Allplex multiplex polymerase chain reactions for the detection of respiratory viruses. Br J Biomed Sci 74 85-89. Link: http://bit.ly/32KDvUd 
22. Shi T, McAllister DA, O'Brien KL, Simoes EAF, Madhi AS, et al. (2017) Global, regional, and national disease burden estimates of acute lower respiratory infections due to respiratory syncytial virus in young children in 2015: a systematic review and modelling study Lancet 390: 946-958. Link: http://bit.ly/2Qi8e8A

23. Ksiazek TG, Erdman D, Goldsmith CS, Zaki SR, Peret T, et al. (2003) A novel coronavirus associated with severe acute respiratory syndrome. N Engl J Med 348: 1953-1966. Link: http://bit.ly/320DdLU

24. (2012) Global Strategy for Asthma Management and Prevention. Link: http://bit.ly/33NBzM3
25. Kyiv Veles LLC (2007) Order of the Ministry of Health of Ukraine No. 128 of March 19, 2007 "On approval of clinical protocols for the provision of medical care in the specialty. Pulmonology 148.

26. Dulek DE, Peebles RS (2011) Viruses and Asthma. Biochim Biophys Acta 1810: 1080-1090. Link: http://bit.ly/2Qoynmh

27. Xepapadaki P, Papadopoulos NG, Bossios A, Manoussakis E, Manousakas T, et al. (2005) Duration of postviral airway hyperresponsiveness in children with asthma: effect of atopy. J Allergy Clin Immunol 116: 299-304. Link: http://bit.ly/2qbFOSZ

\section{Discover a bigger Impact and Visibility of your article publication with}

\section{Peertechz Publications}

\section{Highlights}

* Signatory publisher of ORCID

* Signatory Publisher of DORA (San Francisco Declaration on Research Assessment)

* Articles archived in worlds' renowned service providers such as Portico, CNKI, AGRIS, TDNet, Base (Bielefeld University Library), CrossRef, Scilit, J-Gate etc.

* Journals indexed in ICMJE, SHERPA/ROMEO, Google Scholar etc.

* OAI-PMH (Open Archives Initiative Protocol for Metadata Harvesting)

* Dedicated Editorial Board for every journal

* Accurate and rapid peer-review process

* Increased citations of published articles through promotions

* Reduced timeline for article publication

Submit your articles and experience a new surge in publication services

(https://www.peertechz.com/submission).

Peertechz journals wishes everlasting success in your every endeavours.

Copyright: (C) 2019 Kukalo O. This is an open-access article distributed under the terms of the Creative Commons Attribution License, which permits unrestricted use, distribution, and reproduction in any medium, provided the original author and source are credited. 